\title{
Unraveling the Right of Return
}

\author{
Adina Friedman
}

\section{Abstract}

Thenotion of Return in many ways epitomizes the IsraeliPalestinian conflict. The Palestinian Right of Return, one embodiment of this notion, has constituted a hurdle in the parties' attempts to reach a sustainable agreement. Rather than regard the conflict as of zero-sum nature, this paper assumes that Palestinians and I sraelis, in their negotiations on the Right of Return and other issues, do not hear each other, and in fact are seldom speaking the same language even when it seems they are discussing the same issue. It examines the ways in which I sraelis and Palestinians understand the issue of Return, and suggests a number of factors that influence their different understandings - as well as what each is able to hear from the other. A sustainable agreement would have to take these factors into account in its formulation and in the way in which it is delivered to both peoples.

\section{Résumé}

La notion de $D$ roit au retour incarne le conflit israélo-palestinien de plusieurs manières. Le D roit au retour des Palestiniens est I'une des incarnations de cette notion, et il s'est révélé être un obstacle dans la recherche d'un accord durable entre les deux parties. Plutôt que de considérer le conflit comme étant de nature « jeu à somme nulle», cet article propose la thèse que dans leurs négociations sur le Droit au retour et sur d'autres questions, $\mathrm{Pa}$ lestiniens et I sraéliens n'entendent pas vrai ment ce qu'ils se disent l'un l'autre. En fait, ils parlent rarement le même langage même lorsqu'ils semblent discuter de la même question. L'article examine la manière divergente dont Palestiniens et I sraéliens comprennent la question du Retour, et propose comme explication un certain nombre de facteurs qui pèse aussi bien sur leur compréhension divergente que ce qu'ils arrivent à entendre les uns des autres. Tout accord durable devra prendre ces facteurs en ligne de compte, aussi bien dans sa formulation que dans la façon dont il sera présenté aux deux peuples.

\section{Introduction}

he notion of "Return" is central in the collective memories and national ethos of Jews and Palestinians. For Jews it has, for millennia, carried mainly religiousconnotations, whilein more recent history itsmeaning has become - for Jews and Palestinians alike - mostly political, in many ways epitomizing the Israeli-Palestinian conflict and embodying its very essence. The issue has thus far constituted a hurdlein thetwo peoples' attempts to reach a sustainable, peaceful agreement. Notions of Return are closely linked to the concepts of "Diaspora" and "refugees," and all are, in the given context, most clearly embodied in the idea of the "Right of Return," as it applies to Jews and Palestinians alike.

While there is much to say about Jewish Return, this paper will focus on the Palestinian Right of Return as an important issue in Palestinian-I sraeli negotiations and a central concept in the conflict. H owever, it will make reference to Jewish notions of Return, which have existed for millennia, in order to help clarify Jewish attitudes towards, and understandings of, the Pal estinian Right of Return.

In the eyes of some, the Right of Return constitutes, in a sense, the bare bedrock ${ }^{1}$ upon which other layers of the conflict are mounted, and discourse and discursive processes surrounding it mirror larger processes taking place within the context of the conflict.

On the one hand, the Jewish Right of Return - institutionalized through Israel's Law of Return - is a central element of the Jewish national ethos (at the core of Zionism) and a main tenet upon which the State of I srael was established. Similarly, the Palestinian Right of Return is a central constituent of Palestinians' collective identity and national aspirations. Each people views the right as unquestio- 
nableand irrevocablewith regard to itself, whileillegitimate at best with regard to the other.

A resolution, or agreement, concerning the Right of Return is essential to any future sustainable peace, though it is still one of the main stumbling blocks on the road to reaching an agreement. ${ }^{2} \mathrm{O}$ ne of the many myths prevalent during the 0 slo Peace Process, mainly among I sraelis, was that the "occupation" (of the West Bank and Gaza) was all that stood in the way of reconciliation. ${ }^{3}$ Recent events, especially the Intifada raging since September 2000, suggest that the Right of Return, in fact intrinsically related to the eruption of the Intifada in the first place, is very much alive and still very pertinent.

In Palestinian-Israeli negotiations in Taba, in December 2000-January 2001, an agreement regarding Palestinian Refugees was almost reached, yet for a number of reasons it was not signed. In spite of this very significant breakthrough, those who might have signed such an agreement would have likely had a very difficult time delivering it to their respective constituencies.

\section{A D ialogue of the Deaf?}

The conflict's intractability is often attributed to mutual misconceptions, though someclaim that in fact Pal estinians and I sraelis know exactly what theother sidewants, and that this is incongruent with what they themselves want. ${ }^{4}$ This may explain some of what takes place, mainly, perhaps, at the top leadership level. But it does not, I believe, account for the whole story.

The Right of Return is one of the most difficult and sensitive topics for Palestinians and Israelis to deal with because it hits at the very heart of the conflict. It cannot be truly addressed without tackling other core issues, such as the parties' legitimacy and right to exist as sovereign in the land, and the responsibility for the events of 1948. While much of the discussions and agreements reached in the context of the Oslo Accords consider 1967 as a reference point, the Right of Return forces the parties to deal with the history and consequences of 1948, and possibly even earlier.

The different understandings of and reactions to the Right of Return stem not only from the different political realities in which Palestinians and Israelis live, but largely from the different symbolic repertoires, manifested through culture and language, in which Israelis and Palestinians are immersed and operate. ${ }^{5}$

The conflict is usually seen as one of zero-sum nature, and the Right of Return, more than anything else perhaps, embodies this mutual exclusivity of claims and existence. The impasse with regard to the Right of Return is thus significantly related to its practical ramifications, as well as to the different understandings of the issue (based on cul- tural and linguistic contexts) and its place at the very heart of the conflict. The nature of the interaction between these factors, and their relative salience, must be better understood if an agreement or resolution of some sort is to be reached.

Whether being "deaf" is a circumstantial phenomenon or a strategic choice, a "dialogue of the deaf" seems to be taking place around the Right of Return, related to and indicative of Palestinian-I sraeli communication at large. Some leaders have been close to reaching an agreement of some sort. They have, perhaps, come a long way in trying to untangle the difficult knot the issue constitutes. However, Israeli and Palestinian societies at large are still not really hearing anything but themselves. Some of the crucial questions remaining are why this is the case: Why does the issue indeed constitute such a hurdle? Is it really of zerosum nature? Why does it seem that neither side is able to hear what the other is saying, or see the issue in shades of gray, rather than in black or white?

In order for any progress to be made, it is essential to understand why neither people hears the other, what might enable them to hear each other better, and ultimately what might be an outcome that both peoples could accept and live with. If we somehow unravel the issue, decipher what each people is actually saying, what dynamics influence the discourse on the Right of Return, and why each people seems to be "deaf" to the other, we could perhaps come up with a resolution that not only addresses the issue, but words and delivers it in a way that can be heard and accepted by both.

\section{The Right of Return: Some Legal and H istorical Landmarks}

The Palestinian Right of Return is based on UN Resolution 194, which states that:

[T] her refugees wishing to return to their homes and liveat peace with their neighbors should bepermitted to do so at the earliest practical date, and... compensation should be paid for the property of those choosing not to return and for loss or damage to property which, under principles of international law or in equity, should bemade good by the governments or authorities responsible. $^{6}$

The centrality of the Right of Return in the conflict has gone through several stages. At theend of the $1948 \mathrm{~W}$ ar the Israeli government expressed its willingness to absorb one hundred thousand refugees, approximately 15 per cent of the Palestinian refugees in 1949. Around thirty thousand returned through "family reunification," but the problem of all the rest was left unresolved. Until 1967 the refugee issuewas at thetop of theagenda of thePalestineLiberation 
Organization (PLO) (since its establishment) and the Arab states. However, after the 1967 war and the ascent of the PLO as the sole representative of the Pal estinian people, the refugee issue became less openly prominent; instead, the issue of Palestinian self-determination was now central. In reality, however, the PLO continued to demand the Right of Return and the refugees' plight was one of its main sources of power. ${ }^{7}$

The M iddle East peace process, initiated in Madrid in 1991, recognized the issue of refugees as one which must be addressed on both regional (Arab-Israeli) and bilateral (Palestinian-Israeli) levels. In the framework of the Oslo Accords of 1993, the issue of refugees, along with those of Jewish settlements, borders, water, and Jerusalem, was to be addressed at the "final status" negotiations, which were initially to have been concluded within five years. ${ }^{8}$

The Refugee W orking Group (RWG) was established in 1992, under the framework of the Arab-Israeli multilateral peace talks generated in M adrid, and later on, in 1995, the Continuing Committee for Displaced Persons was established. ${ }^{9}$ Ever since, the refugee issue has been addressed in various forums, mainly in second-track diplomatic efforts (these included participants from Israeli and Palestinian NGOs, as well as policy and opinion makers).

Understanding the issue's complexity, discussions concerning it were left to the final stages of negotiations between Israel is and Palestiniansin the framework of the 0 slo Accords. ${ }^{10} \mathrm{~N}$ ot surprisingly, the collapse of the 0 slo talks in the summer of 2000 was cl osely linked to impasses between the parties with regard to the Right of Return. ${ }^{11}$

At the Taba negotiations in late 2000 and early 2001 a breakthrough was made, though mostly on an individual level, by a few negotiators who did not necessarily rep resent the general feelings among their respective two peoples and who, at that point, may not have been able to deliver such an agreement had it been signed. ${ }^{12}$

Furthermore, the centrality of the refugees and refugee camps in the Palestinian struggle and steadfast resistance during the current Intifada, on the one hand, and the harsh Israeli "reprisals" particularly in recent months, geared mainly at the camps, on the other hand, is not coincidental. The refugee camps have al ways served as one of the main "hotbeds" of Palestinian nationalism, and much of the Palestinian resistance has thus emanated from the camps. The refugees in many ways epitomize the essence of the Palestinian struggle, and the refugees were the ones who feared being forsaken by the Palestinian leadership were unsatisfactory agreements to be signed which would have relinquished their rights. In addition, since the signing of the Oslo Accords, the situation on the ground for refugees had worsened, mainly in that the per capita income (via
UNRWA) was lower than it had previously been, because of the new ways in which moneys were being funneled. Overall, disillusionment among refugees was extremely high. The centrality of the refugee issue and refugee camps in the September 2000 Intifada is a result of all of the above, and the Israeli reprisals aimed mainly at the camps serve to heighten and perpetuate their centrality.

\section{Jewish/Israeli Notions of "Return," "Refugees," and "Right"}

M odern political Zionism drew upon existing religious notions of a Jewish Return to Zion, which many Jews had harbored over the centuries. For many centuries Jews, who had previously been expelled from the Land of Zion - Israel - saw themselves as living in the Diaspora and awaiting their return to their land. Zionism, which managed to mobilize Jews based on these and other sentiments, and which culminated in the establishment of the State of Israel, remained the hegemonic state ideology. The Return of J ews to their ancestral land, rather than just a religious notion, became one of the cornerstones of the Jewish State.

Notions of "refugee-ness" heightened among Jews following World War II and the Holocaust, and Israel, more than before, came to beviewed a safe haven for J ews around the world. Shortly following the establishment of the State of Israel, thousands of Jewish refugees poured into Israel from various Arab countries due to hostilities and persecution. Israel, in fact, organized campaigns (such as airlifts) aimed at rescuing Jews from these countries. In the early 1950s there were many "transitory" camps ( M a'abarot) in Israel, which were, in essence, refugee camps.

Thus, in the minds of most J ewish I sraelis the notion of refugees refers not only, or even mainly, to Palestinian refugees of 1948 - a loaded and controversial issue in itself - but rather to what they see as a parallel phenomenon of Jewish refugees: first from Europe, and later from Arab lands. Since these Jewish refugees were absorbed into the Jewish state, thereby obliterating the Jewish "refugee problem," there is a refusal to understand or accept that the same was not done on the Arab side. In other words, a parallel is drawn between the Jewish and Palestinian refugee problems, following which thereare parallel expectations from the Palestinians and the Arab world to have resolved the Palestinian refugee problem, and corresponding demands from theArab states to compensatethe ewish refugees. The Palestinian refugee issue is thus linked to the larger issue of $M$ iddle East refugees, and a solution is perceived only in some larger context. The fact that the Palestinians are a different "entity" than any given Arab country from which Jewish refugees fled is irrelevant. In fact, most I sraeli Jews see Palestinians and Arabs as one and the same. 
Jews and Jewish refugees "returned" to their historical homeland - and "home" is perceived as anywhere that Jewish sovereignty exists. It is difficult, therefore, to understand that "home" may mean something slightly different (perhaps much more specific, e.g., a village or town) to most Palestinians.

The closest referent in the J ewish-I sraeli national psyche to the concept of the Right of Return is the Israeli "Law of Return" (based on the Jewish Right of Return), which allows any J ew to immigrate to I srael and become a citizen of the state. This law, adopted by I srael in 1950, was a form of "affirmative action," allowing Jews, previously persecuted and denied rights in other countries, to seek a safehaven in Israel.

The H ebrew word for "Right" (Zekhut) seems to have a legalistic, implementation-based undertone. Thecombination of the Hebrew words "Right" (Zekhut) and "Return" (Shvut, Shiva), which clearly connote the Law of Return in the minds of most I sraeli J ews, strengthens this implementation-based notion. $\mathrm{H}$ ence, perhaps this exacerbates Israelis' difficulty or inability to conceive of a right as having a modified implementation or being separate from its complete actualization, and thus they seemingly cannot avoid the conflation of two (possibly) quite different matters: the Palestinian Right to Return and the actual return of the Palestinians. ${ }^{13}$

\section{Palestinian N otions of "Refugees," "Return," and "Right"}

To Palestinians, May 1948 marked a crucial watershed in their personal and collectivehistory. In the process of population displacement, which continued until the conclusion of the armistice agreements between Israel and Egypt, Jordan, Lebanon, and Syria in 1949, half of Palestine's 1.4 million Arabs were uprooted from their homes and became refugees. The traditional political and social leadership was scattered, and the Palestinian social web was destroyed. These traumatic events of 1947-49, which cost the Palestinian their majority status in Palestine and their hope of controlling the country, and cost half of them their homes, land, and property, areinscribed in Palestinian memory and historiography as al-Nakba, "the Catastrophe."

One of the main elements of Palestinian identity (before 1948 and thereafter) was the attachment to a specific locale - a home, a village, or a city. Given this fact, the impact of the events of 1947-49 was even more powerful. By 1949 morethan four hundred cities, towns, and villages had been depopulated, incorporated into Israel and settled with J ews, and most of their Arab inhabitants became refugees, dispersed throughout the region.
The Catastrophe of 1948, rather than causing the absorption of Palestinian refugees into neighbouring Arab countries, reinforced pre-existing elements of self-definition that were al ready present. In spite of the existence of a variety of different identities, the shared events of 1948 brought the Pal estinians closer together in terms of their collective consciousness, even though physically they were dispersed all over the M iddle East and beyond. 1948 erased many preexisting differences, and the $N$ akba thus came ultimately to serve as one of the most important aspects of Palestinian identity and a source of shared beliefs and values. ${ }^{14}$

The 1967 war was yet another watershed in Palestinian identity, and served to reinforce the Palestinian national movement. On the one hand, the Arab armies had been defeated by Israel, disillusioning many Palestinians who had hoped their salvation would come from neighbouring Arab countries. In effect, 1967 symbolized the end of PanArabism. The Arab countries exhibited and emphasized more localized identities, in line with nation-state boundaries and frames of reference. This change in ideology did not leave much choicefor thePal estinians, who had anyway ceased to put their faith in the hands of other Arab leaders and states. The end of Pan-Arabism was therefore a significant factor in enhancing an independent Pal estinian national identity. ${ }^{15}$

On the other hand, the entire West Bank, previously under Jordanian rule, and in fact all of mandatory Palestine, were now under Israeli control (including the Gaza Strip, previously under Egyptian military rule). Thisended efforts to "Jordanize" the Palestinians, and eventually the pro-Jordanian elite in the West Bank gave way to a Palestinian nationalist elite. It also brought previously separated Palestinian communities together. ThePLO 0 , which was officially formed in 1964, now became a broad-based national movement organized as a proto-state. ${ }^{16}$

For over fifty years there has been an ongoing struggle over the preservation and recreation of the Palestinian identity, which has taken place in a few loci: the refugee camps in the West Bank, Gaza Strip, Lebanon, Syria and Jordan, which preserved the identity of displaced refugees intending to return to their homes; the population in the major Palestinian cities, such as Nablus; and the "satellite" Pal estinian communities in the Diaspora, which eventually served as a hotbed for national and rebellious activities.

Memories of destroyed villages and towns, and of the events of 1948, play a central role in Palestinian consciousness. The Deir Yassin massacre, committed by Irgun forces in 1948, was crucial in heightening Palestinian fears at the time and in heightening the flow of refugees. It has been, ever since, a central theme in the narration of Palestinian history, and has had a great impact on how Palesti- 
nians saw (and still see) their enemies. Palestinian identity has, ever since 1948, been in many ways constructed of the experience of dispossession, homelessness, insecurity, and uprootedness. ${ }^{17}$

No one embodies these feelings more than the refugees themselves. Indeed, the concept of Ghurba, or exile, is a major component of Palestinian identity. In addition, a distinct identity and character developed in the camps themselves, and in those outside the mandatory borders of Palestine the situation was different than that in the West Bank and Gaza Strip camps. A major agent in instilling Palestinian consciences among the camp refugees was the educational system established by the U nited $N$ ations Relief and Work Agency (UNRWA). For many Palestinians, the core of the conflict, from which all else flows, is the refugee issue. They see their dispossession by Israel in 1948 as the defining element in the modern history of their people, as well as in the entire Arab-Israeli conflict. ${ }^{18}$

The term "refugee" does not, in the Palestinian mind, refer only to those living in and around camps and defined by U NRW A as refugees. The concept is a central theme in the personal and collective identity of many Palestinians, and applies to anyone who fled or was forced out of their home, regardless of their official "status" today. Thus, there are in fact many more Palestinians who would identify themselves as refugees than any $U N$ or other figures might show, and "refugee" is more a matter of identity than an operational definition.

The Arabic term for "Right of Return" ( $\mathrm{Haq}$ al-'Awda) resonates very strongly among Palestinians, not merely because of its clear political meaning. The Arabic word for "Right" (Haq) also means, or connotes, justice/justness, truth ("definite," real), and is one of God's names. Thus, the connotations the word itself evokes are of a strong, non-negotiable concept. Its connection to direct implementation is another question, but, regardless, it is a concept over which one cannot conceive of negotiating or compromising; it is simply a "given." The Right of Return has been a central principle in Pal estinian collective identity, and is in fact a central element in the personal identity of many. The refugee issue and the Right of Return are at the heart of the Palestinian national ethos and struggle and enfold memories of the $\mathrm{N}$ akba and the feelings of historical injustice brought upon the Palestinian people.

\section{What Are Palestinians and Israelis Saying and Hearing?}

Palestinian and I sraeli narratives of the past are, more often than not, mutually exclusive. The debate over the Right of Return epitomizes these mutually exclusive narratives, and any principal position-shift on theissue is perceived by each peopleto have potential detrimental consequences, on both practical and symbolic levels. On the practical level this is perceived to mean "flooding" Israel with refugees and thus destroying it, on the one hand, or leaving unresolved the condition of millions of refugees on theother. On a symbolic level such a position-shift would strike at the core of each people's national narrative and collective identity, challenging at once well-established self-perceptions and deeply held beliefs about the "other."

For most Israelis, the Right of Return has traditionally been a taboo, and means nothing less than four million refugees at I srael's doorstep the next day. Israel is show little ability to conceptualize a right separate from its full actualization, and their main reasoning against the Right of Return is that it will indeed destroy the State of I srael as a Jewish state, and perhaps altogether. In other words, it has both demographic and security-related consequences. Palestinians' insistence on their right to return casts them, in the eyes of Israelis, as seeking to overwhelm Israel with refugees - in other words, seeking I srael's destruction. ${ }^{19}$ If they do refer to 1948, Israelis for the most part cast the blame for the creation of the refugee problem on the Palestinians themselves and on the Arab regimes, taking little blame, if any, for themselves. At best, the events of 1948 are viewed as natural, or excusable, wartime occurrences.

Following this rationale, Israeli discourse has tended for many years to treat the refugee issue as a humanitarian one first and foremost, and any possible action by I srael on this issue, such as admitting a small number of refugees into Israel, is framed as a humanitarian act or favour which I srael is willing to grant the Pal estinians as a gesture of good will. Indeed, such a gesture can only be considered if it is framed by Israel as such, explicitly denying any Israeli responsibility, even partial, for the creation of the refugee problem. Thisposition was reiterated and emphasized once again by Israeli Prime Minister Barak in the summer of 2000.

Even among I srael's traditional "peace camp" it is difficult to find proponents of the Right of Return. A few months into the current Intifada some of Israel's leading intellectuals (all from the I sraeli peace camp) issued, in the Israeli press, a letter to the Palestinian leadership. After noting that they have struggled for over thirty years for the two-state solution, the signers forcefully stated that they shall never be able to agree to the return of the refugees to within the borders of I srael. I nstead, they affirmed that "the refugees will have the right to return to their homeland, Palestine, and settle there." H ereagain, theletter's signatories appear to be understanding the issue no differently from the general public: confusing the issues of the right and its actual actualization, and rejecting the key Palesti- 
nian demand for recognition of their right to return to their homes in Israel as well as in the Occupied Territories.

Palestinians, on the other hand, emphasize the political nature of the problem, and the need for principle recognition by Israel of its responsibility, whole or partial, for the events of 1948 and the fate that consequently befell the Palestinians. To justify and anchor their claims, Palestinians refer to various UN resolutions (mainly 194) and to concepts of international law in general.

Importantly, notions of "Justice" (also inherent in the word $\mathrm{Haq}$ ) are central to Palestinian claims, while the concept is usually absent in Israeli discourse. There is a great emphasis on the righting of a grave historical wrongdoing. While Israelis highlight the notion of "symmetry" between Jewish and Arab refugees, Palestinians emphasize the notion of "equality" and the lack thereof in the relationship between Israelis and Palestinians. If symmetry is refer red to by Palestinians, it is in a different context, mostly comparing I sraeli claims and retributions from Germany to Palestinian claims from Israel.

Palestinians also stress the notion of "choice," referring to a personal choice of each refugee. A choice not to return to one's home would not imply "giving up" the Right of Return, but rather would mean that while the right is a given, the mode of its exercise is a matter of choice. This concept is mostly absent in Israeli discourse, since in the concept itself lies one of Israel's greatest fears - the fear that all four million refugees would in fact chose to return to their homes within the 1967 borders of I srael.

Embedded in this concept of choiceis the notion that the Right of Return is a personal right before it is a collective right. M oreover, to Israelis, "being home" implies, for most people, living under Israeli sovereignty. In other words, sovereignty is an attribute of a collective, and Return of the Jews (both a collective and a personal right) is to this collective, sovereign entity. It is difficult for Israelis to conceptualize the much more salient attachments Palestinians have to their particular place (city, village, house) of origin. While notions of nationality, statehood, and sovereignty are dynamic and ever evolving, it is still difficult to say at this point that most Palestinian refugees regard anywhere under Palestinian national sovereignty as "home."

Some Palestinians and Israelis go as far as devising a concrete plan for the return of all refugees, and claim to prove that such a solution is entirely feasible and does not pose any threat to Israel, or that such a threat, if it exists, is irrelevant. ${ }^{20}$ This claim, while perhaps "technically" convincing, is not entirely useful. Just as Israelis tend to underestimate or completely overlook the meaning Palestinians attribute to the issues of "refugees" and "Return," so do such plans tend to ignore, or deem unimpor- tant, Israeli fears (demographic and security-related). The issue of "physical space" to absorb the refugees is hardly the most central concern of most Israelis.

Thegeneral run of Palestiniansfor themost parthold (or at least widely express outwardly) maximalist demands with regard to the actualization of the Right of Return. ${ }^{21}$ In a sense, the Palestinians are entrapped in their demand to recognizetheRight of Return. They haveinvested too much in trying to secure this right, and would lose face (to others as well asto themsel ves) if they did not achieve a satisfactory agreement of some sort. H owever, most Palestinian leaders and intellectuals (as well as others) arewell aware that Israel is unlikely to agree to the actual return of all refugees. For the most part, the Pal estinian leadership seeks someformal and principle recognition of Palestinian rights and a choice-based approach which will provide the refugees with a variety of structured options. These options, which would be accompanied by a variety of incentives and disincentives, may beformulated in a way such that only a few will actually choose to return to I srael. ${ }^{22}$ The formulation of this approach, however, must also satisfy (at least to some degree) the Palestinians' need, or demand, for an official acceptance of responsibility on the part of the state of Israel.

Another important difference between Palestinian and Israeli discourses is that while Israelis tend to be forwardbound - taking historical points of reference (mostly 1967) as "instrumental" (mainly to themselves, since preserving some sort of status quo better serves the stronger party in the conflict) in reaching a future solution - Palestinians are still very much bound to the past, to the events of 1948. Moreover, whilel sraelisemphasize an "end to theconflict," Pal estinians express more concern with historical justice.

\section{What Does All ThisTell Us?}

Conflict, in effect, can be conceptualized as a constructed discourse. Conceptualizing the "Right of Return" as such places it within the wider discursive and institutional continuities within which it is embedded..$^{23}$ Thus, discourseregarding the Right of Return must be examined in relation to discourses about the conflict at large, as well as discourses on identities, history, etc., prevalent among Pal estinians and Israelis. Examining the nature of, and reasons for, the apparent impasse with regard to the Right of Return may indeed shed light on, and be informed by, the larger context of the conflict.

Discussion between I sraelisand Palestinians on the Right of Return in particular, and on the conflict in general, takes place on different discursive planes, since the different realms of meaning upon which the discourses draw have little, if anything, in common. Theseseparate discourses both construct and delimit each peoples' own reality, as well as 
their interpretations of the other's reality. As Khalidi puts it:

In a sense, each party to this conflict, and every other claimant, operates in a different dimension from the other, looking back to a different era of the past, and living in a different present, al beit in the very same place. ${ }^{24}$

The "Dialogue of the Deaf" between Palestinians and Israelis, or the entanglement surrounding the Right of Return, is the result of a number of different factors and most likely a combination of them all: their worlds of meaning are incongruent with one another, and concepts reverberate very differently - linguistically, culturally and otherwise - within both communities. Language, culture, and discourse all have features in common, as claims Foucault: they belong, within a given context, to the same system of formation and serve to construct and delimit the way people make meaning of the world around them.

At face value it seems that when discussing the Right of Return Pal estinians and Israelis are talking about the same thing and simply not agreeing on it; in other words, that the demands, or aspirations, of both sides with regard to the Right of Return are simply irreconcilable and that the conflict is indeed of zero-sum nature. A closer look, however, reveals that not only is each side often not really hearing what the other is saying but that this "Dialogue of the Deaf" is one of the central symptoms of the conflict, as well as a main cause for its perpetuation.

"Peace talks" between Palestinians and Israelis mostly regard 1967 as the significant point of reference. This symbolizes a "compromise" and mutual recognition between Palestinians and Israelis, and supposedly constitutes a workable framework for future political arrangements. H owever, this framework al so enables the parties (mostly I srael, for whom the "status quo" is more convenient) to avoid confronting the origins and core of the conflict - which in the eyes of Palestinians in fact lie further back in history. W ithdrawal of Israeli troops from the W est Bank and Gaza and even the dismantling of settlements in those areas are more technicalities, or "cosmetics," which treat the actual physical occupation of Palestinians civilians by Israelis as the main source of the overall conflict. While most may agreethat this is the most immediate source of conflict, and especially of its escalation over the past two years, for Palestinians 1948 still constitutes the formative event in their collective national history as well as in the personal history and memory of many, and the real core of the conflict.

The difference in interpreting the Right of Return portrays, among other things, the debate over responsibility for the events of $1948,{ }^{25}$ as well as the different historical landmarks to which each party is alluding. The recognition by Israel of a Palestinian Right of Return even in principle is problematic, since it would challenge the Israeli national identity and meta-narrative by implying responsibility for the fate of the Palestinians, and possibly cast a shadow on Israel's righteousness and legitimacy (cornerstones of the Jewish/Israeli national ethos). N ot only are the issues of the war or the fate of the refugees problematic, but the fact that Israel possibly could not have come into being, or survived, without the drastic demographic shift in its favour due to the expulsion and fleeing of so many Palestinians, is a hard issue for Israel to confront. Thus, for Israelis, accepting the Palestinian Right of Return (together with a share of the responsibility for the formation of the Palestinian refugee problem) is seen as having detrimental consequences. For Palestinians, relinquishing the Right of Return would render over fifty years of struggle meaningless. In fact, the very core of the Palestinians' identity and plight would be left unanswered.

Conveniently, it has been possible to discuss, albeit somewhat superficially, all other technicalities while evading the core of the conflict. In other words, being "deaf" has often been a strategic choice consciously madeby Israelis and Palestinians (mostly the leaders), which has served their different agendas, and has not prevented them from reaching a number of agreements. However, the sustainability of these agreements is in question so long as other core issues, such as the Right or Return and all it entails, remain unresolved. Real reconciliation can begin only once the weight of history has been shouldered. ${ }^{26}$ Once the conflict's bedrock lies bare there may be no choice left but to finally confront it.

Mutual deafness, or blindness, in fact exists between Israelis and Palestinians throughout their relationship and negotiations at large, with regard to most issues pertaining to the conflict and the peace process. To overcome this obstacle, the importance of which is usually underestimated, it is necessary to recognize that I sraelis and Palestinians indeed do not hear each other, do not see each other, and do not understand each other's realities. Even when they are seemingly discussing the same issue, they may in fact attribute to it enti rely different meanings. Currently, Palestinians and I srael is operate in completely different realms of meaning, with hardly any overlap. Whileshared meaning may be too much to ask for at this point, compatible meanings are more attainable. A sustainable agreement would thus need to be worded and delivered in a way that addresses the core concerns of Pal estinians and Israelis and resonates well with both peoples.

In trying to reach a sustainable agreement it is also important to recognize that meaning is dynamic, subject to 
the workings of discursive and other processes, and that the past as well as the future are looked at from within the context of the present. What seems unbridgeable and inconceivable today may well be possible tomorrow, if we better understand theseprocesses. The Right of Return, too, may come to mean something different than it currently does to Palestinians and to Israelis once their respective political realities change.

Overcoming existing hurdles will also require new and creative ways of thinking and the continuous challenging of long-held myths and deep-seated taboos. $\mathrm{N}$ ot only will the past haveto bere-examined, so will therange of conceivably possible future scenarios.

\section{Notes}

1. David K. Shipler, "A Conflict's Bedrock Is Laid Bare," New York Times, 27 M ay 2001.

2. Jerome M. Segal, "Clearing up the Right of Return Confusion," Middle East Policy 8:2 (2002): 23.

3. Shipler, 2001.

4. Ian Lustik, "Yerushalayim and al-Quds: Political Catechism and Political Realities," Journal of Palestine Studies 30:1 (Autumn 2000): 5.

5. Raymond Cohen, Culture and Conflict in Egyptian-Israeli Relations (Bloomington: Indiana U niversity Press, 1990).

6. Primer: The Palestinian Right of Return (Washington, D.C.: American-Arab Anti-Discrimination Committee, September 2000).

7. U riah Shavit and Jalal Bana, "The Palestinian Dream - The Israeli Nightmare," Haaretz D aily, 7 June 2001.

8. Abu Shakrah, Palestinian Refugees: A Discussion Paper (Philadelphia, PA: American Friends Service Committee, Middle East Program, January 2000).

9. Salim Tamari, Palestinian Refugee N egotiations: From M adrid to O slo II (Washington, D.C.: Institute for Palestine Studies, 1996).

10. Ibid.

11. Ilan Pappe, "Israeli Perceptions of the Refugee Question," Palestinian Refugees: The Right of Return, ed. Naseer Aruri (London: Pluto Press, 2001).

12. Based on comments made in private talks with a number of negotiators.

13. Jerome M. Segal, 2000.

14. Rashid Khalidi, Palestinian Identity: The Construction of M odern N ational Consciousness ( N ew York: Columbia U niversity Press, 1997).

15. M eir Litvak, "A Palestinian Past: National Construction and Reconstruction," History and M emory 6:4 (1994).

16. Ibid.

17. Helena Lindholm, "Palestinian National Identities: Change and Continuity of the Palestinian as a Struggler," in Ethnicity and Nationalism: Formation of Identity and Dynamics of Conflict in the 1990s (Sweden: NORDN ES \& PADRIGU/Göteborg University, 1993).
18. Rashid Khalidi, "Attainable Justice: Elements of a Solution to the Palestinian Refugee Issue," International Journal 5:2 (1998): 232-52.

19. Abu Shakrah, 2000.

20. Salman Abu Sitta, Palestinian Right to Return: Sacred, Legal and Possible (London: Palestinian Return Centre, 1999).

21. Jerome M. Segal, 2000.

22. Rashid Khalidi, 1998.

23. Vivienne Jabri, Discourses on Violence ( $M$ anchester and $\mathrm{N} \mathrm{ew}$ York: M anchester University Press, 1996).

24. Rashid Khalidi, 1997.

25. Jerome M. Segal, 2000.

26. Rashid Khalidi, 1998.

Adina Friedman holds an M .A. in M iddle East History from Tel Aviv U niversity, Israel, and an M.S. in Peace and Development from Göteborg U niversity, Sweden. She is currently a Ph.D. candidate at the Institute for Conflict Analysis and Resolution, George M ason U niversity, in Fairfax, Virginia. 